\title{
Multimodal imaging in assessment of left atrium appendage
}

\author{
Damir Raljević, \\ Davorka Žagar, \\ Vesna Pehar \\ Pejčinović*, \\ Viktor Peršić, \\ Dijana Travica Samsa, \\ Ivo Kalčić, \\ Ingrid Buljanović
}

Clinic for Treatment, Rehabilitation and Prevention of Cardiovascular Diseases, Thalassoterapia Opatija, Opatija, Croatia

\author{
KEYWORDS: multimodal imaging, left atrium appendage. \\ CITATION: Cardiol Croat. 2017;12(4):130. I https://doi.org/10.15836/ccar2017.130
}

*ADDRESS FOR CORRESPONDENCE: Vesna Pehar Pejčinović, Thalassotherapia Opatija - Klinika za liječenje, rehabilitaciju i prevenciju bolesti srca i krvnih žila, UI. Maršala Tita 188, HR-51410 Opatija, Croatia. Phone: +385-51-202-720 / E-mail: pehar.vesna@gmail.com

ORCID: Damir Raljević, http://orcid.org/0000-0001-9743-9201 • Davorka Žagar, http://orcid.org/0000-0002-0914-6810 Vesna Pehar Pejčinović, http://orcid.org/0000-0002-8921-7999 • Viktor Peršić, http://orcid.org/0000-0003-4473-5431 Ivo Kalčić, http://orcid.org/0000-0001-7724-7296



Atrial fibrillation is an important factor associated with left atrium (LA) enlargement and thrombus formation in the LA appendage. Transesophageal echocardiography is the procedure of choice for assessment of dimension of the LA, as well as thrombus detection in the LA cavity or LA appendage. It can detect thrombi with a high degree of sensitivity and specificity varying from $93 \%$ to $100 \%$. Cardiac CT represents a gold standard for the assessment of anatomy of the LA complex. The mean CT sensitivity for identifying thrombus in the LA was $81 \%$ and the mean specificity $90 \%$. Because of the high spatial resolution and the excellent myocardial border detection magnetic resonance imaging (MRI) is considered the most accurate technique for the non-invasive assessment of atrial volumes. Cardiac magnetic resonance imaging helps in tissue characterization of various intra-atrial masses and thus differentiation between cardiac tumors and thrombi. Both CMR and cardiac CT currently represent very important imaging modalities used for the comprehensive evaluation of the LA. ${ }^{1-3}$

In our work we show a small series of patients with suspected mass in the LA appendage on the transesophageal ultrasound in which a cardiac MSCT and/or cardiac MRI is performed
RECEIVED:

March 11, 2017

ACCEPTED:

April 6, 2017

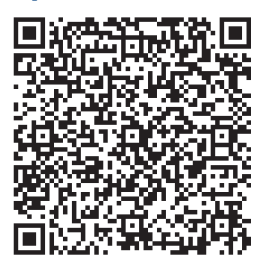



1. Tops LF, van der Wall EE, Schalij MJ, Bax JJ. Multi-modality imaging to assess left atrial size, anatomy and function. Heart. 2007 Nov;93(11):146170. https://doi.org/10.1136/hrt.2007.116467

2. Wu X, Wang C, Zhang C, Zhang Y, Ding F, Yan J. Computed tomography for detecting left atrial thrombus: a meta-analysis. Arch Med Sci. 2012 Dec 20;8(6):943-51. https://doi.org/10.5114/aoms.2012.32400

3. Romero J, Husain SA, Kelesidis I, Sanz J, Medina HM, Garcia MJ. Detection of left atrial appendage thrombus by cardiac computed tomography in patients with atrial fibrillation: a meta-analysis. Circ Cardiovasc Imaging. 2013 Mar 1;6(2):185-94. https://doi.org/10.1161/CIRCIMAGING.112.000153 